\title{
MEASURING RETAIL SERVICE QUALITY IN TERMS OF CUSTOMER PERCEPTION OF MULTI-BRAND RETAIL STORES-A STUDY WITH SPECIAL REFERENCE TO SHOPPERS STOP IN INDIA
}

\author{
RAJEEV KUMAR \\ Faculty-Retail \\ Footwear Design and Development Institute, \\ Rohtak, Haryana \\ rajeev.kumar595@gmail.com
}

\author{
MRS. PARVEEN MAAN \\ HOD \& Sr. Faculty-Retail \\ Footwear Design and Development Institute \\ Rohtak, Haryana
}

\begin{abstract}
In the recent years, service quality has become one of the most researchable disciplines. The researches proved that high retail service quality leads to high performance of the retail organisations. The present study aimed at measurement and analysis of retail service quality dimensions (RSQS) at multi-brand retail store located in India. The purpose of this study was to find out how customer perceives the overall retail service quality and his satisfaction level towards a multibrand retail store. The present study mainly focuses on service quality measurement in Shoppers Stop, which is among one of the leading multi-brand retail stores in India. On the basis of literature, limited service quality measurement studies with regards to multi-brand retail stores are available in India. A survey of 300 shoppers of Shoppers Stop from national capital region (NCR) of Delhi has evaluated retail service quality on seven point likert scale. The study used Retail Service Quality Scale (RSQS), which composed of 5 dimensions namely physical aspects, reliability, personal interaction, problem solving and policy. The results showed significant relationship among the RSQS dimensions and customer satisfaction of retail customer in multi-brand retail.
\end{abstract}

Key words: Retail Service Quality, multi brand retail stores, shoppers, RSQS scale.

\section{Introduction}

Retailing is the final chain that links the manufacture and individual consumer. Indian economy has been experiencing significant rise in formal retailing like departmental stores, hypermarkets, super markets and online retailing. Many retail organisations 
started retail activities using their own store brands. The present study mainly focused on measuring Retail Service Quality in terms of Customer Perception of Multi-Brand department Store i.e. the Shoppers Stop and the study was carried out in national capital region (NCR) of Delhi. A department store is a retail concern which focuses in fulfilling an extensive range of the individual and housing durable goods, product needs and offering the shopper a choice of multiple products lines, at different price, in all product groups, Raja ram \& Sriram (2014). Shoppers Stop began by operating a chain of department stores in 1991 under the name "Shoppers Stop" in India. Shoppers Stop has 74 stores across 35 cities in India. Shoppers Stop retails clothing, accessories, handbags, shoes, jewellery, fragrances, cosmetics, health and beauty products, home furnishing and decor products. Shoppers Stop launched its e-store with delivery across major cities in India in 2008. The Shoppers Stop website retails all the products available at Shoppers Stop stores, including apparel, cosmetics and accessories. Service quality is taken as an important factor to increase the satisfaction of the customers and customer loyalty in service settings.

\section{Service Quality}

Service quality is "a global judgment, or attitude, relating to the superiority of the service" (Parasuraman, Zeithaml and Berry, 1988). There has been a continued research on the definition, modelling, measurement, data collection procedure, data analysis etc., issues of service quality, leading to development of sound base for the researchers. All the researches have brought service quality topic on another level by exploring more possibilities to measure, analyse and conclude about service quality as a significant issue to study. The important issues of service quality performance were 
discovered in order to investigate the methods for the service quality improvement.

Fornell (1992) elaborated that high customer satisfaction will result in increased loyalty for the firm and that customers will be less prone to overtures from competition.

Sivadas and Backer-Prewitt (2000) highlighted that the excellent service quality can be delivered by high performance of employee in the store. They further asserted that the service-oriented employee is able to deliver high retail service quality to the customer. Owing to this, service-oriented employee let customer feels favourable service experiences and excellent service quality. In this way, retail employee should understand the customer's service experience process so well that adds value to his shopping process. Ramayah and Jasmine (2003) studied on apparel stores and found that each service quality dimensions have positive and strong relation with other service quality dimensions. Ramayah and Jasmine (2003) studied service quality provided by apparel stores and found that each service quality dimensions had positive and strong relation with other service quality dimensions. According to Seth and Deshmukh (2005), the service quality enable management to identify quality problems and helps in planning for the launch of a quality improvement program thereby improving the efficiency, profitability and overall performance of the store. Oyeniyi and Abiodun (2012) studied on Nigerian departmental stores and highlighted that RSQS dimensions had significant relationship with store's customer satisfaction.There are limited studies available regarding the measurement of service quality and its relation with customer satisfaction of multi-brand retail in Indian context. That is why; the present study was conducted to measure retail service quality in terms of customer perception of multi-brand 
retail stores with special reference 'Shoppers Stop'. The study also measured the customer satisfaction and behavioural intentions of shoppers of the multi-brand department store.

\section{Research Questions}

The main issues addressed by this research were 'retail service quality' and 'customer satisfaction' using the RSQS model in departmental store context. The researchers were interested in measuring the overall retail service quality in the Shoppers Stop.

Accordingly, research questions are brought forward as follows:

- How does customer perceive the overall retail service quality provided by departmental stores?

- Does the customer satisfy with the overall retail service quality provided by departmental stores?

\section{Objectives of the Study}

1) To analyze the customer satisfaction of department store towards service quality provided.

2) To analyze the relationship among RSQS dimensions and customer satisfaction.

3) To find a relationship among RSQS dimensions, customer satisfaction and customer Behavioural Intentions.

\section{Research Methodology}

The current study was conducted in National capital region (NCR) in India. The study surveyed 300 retail customers from Shoppers stop on convenience basis in 2015. The validated Retail Service Quality Scale (RSQS) which was developed by Dabholkar et al. (1996) was utilized in this study. The scale consisted of 28 items to measure the retail service quality of retail store. The customer satisfaction was measured using three questions based on American 


\section{ELK ASIA PACIFIC JOURNAL OF MARKETING AND RETAIL MANAGEMENT}

ISSN 2349-2317 (Online); DOI: 10.16962/EAPJMRM/issn. 2349-2317/2015; Volume 6 Issue 4 (2015)

Marketing Index Fornell, Johnson, Anderson, Cha and Bryant (1996). The behavioural intentions were measured by asking three questions. All the items were asked on seven point likert scale. Only those respondents were recruited for the survey who has shopped from selected retail brand in last 30 days. The data so collected was finally prepared in excel sheets and analysed using Reliability Analysis, Arithmetic mean, Standard deviation, Karl Pearson coefficient of correlation and Linear Multiple regression. The hypothesis testing was performed using t-test and ANOVA (F-test).

\section{Data Analysis and Discussion}

The researchers surveyed a sample of 300 respondents out of which $55 \%$ are below the age of 32 . Only $10 \%$ of the respondents were above the age of 46 and $35 \%$ of the respondents belong to age group 33-46 years

(Refer figure 1.1 here). The sample consists of a majority of female customers (Refer figure 1.2 here). The females respondents comprise $58 \%$ of the sample and $42 \%$ of the sample is represented by male customers of Shoppers Stop. The figure 1.3 represents the percentage of customers based on years spent with shoppers stop (Refer Figure 1.3 here). All in all $68 \%$ of the customers have been shopping from shoppers stop for more than 3 years and around $37 \%$ of the customers have spent more than 6 years shopping from the store. From the data collected that $62 \%$ of the customers are using physical place shopping method and $38 \%$ use online way of shopping from the store. Figure 1.4 depicts the shopping frequency of the customers. (Refer Figure 1.4 Here) 
Comparing CSAT among age groups, years with Shopper Stop and shopping frequency

The F-test conducted to study the customer satisfaction among age groups. The F-test results showed that among the five age groups, the customer satisfaction of age groups $26-32 \&>46$ is significantly higher than the age group of 18-25. This represent that young customers are less satisfied with Shoppers Stop services. The F-test value 5.22 significant at $\mathrm{p}<0.01$, revealed that the customers who have been shopping from Shopper Stop for more than 9 years are significantly more satisfied than the other customers with less years spent with the store. While studying customer satisfaction on the basis of shopping frequency, it was found that the customer satisfaction of all customers found to be not significantly differing.

\section{Retail Customer's Satisfaction (RCSAT) \\ \& Retail customer's behavioral Intentions (RCBI)}

Table 1.1 shows the correlation between RCSAT and RCBI. This indicates that the correlation coefficient ' $r$ ' $=0.818$ is significant at $\mathrm{p}<0.01$. It reveals that the satisfied customer is likely to repeat its purchases and he is likely to recommend Shoppers Stop to its friends. (Refer Table

\subsection{Here)}

\section{Retail service quality scale (RSQS)}

dimensions and Retail Customer

\section{Satisfaction (RCSAT)}

The Linear multiple regression analysis using stepwise method was used to predict the RCSAT in terms of RSQS dimensions. The multiple regression analysis indicated that RSQS dimensions personal interaction, problem solving, reliability and physical aspect (independent variable) combined 
together appear to explain RCSAT (dependent variable) with ' $r$ ' $=0.82$, r-square $=0.67$ and adjusted $\mathrm{r}$-square $=0.66$. The regression model fit the data with F-test= 151.60 , significant at $\mathrm{p}<0.001$. The reliability dimension of RSQS negatively correlated with RCSAT. The policy dimension did not find relevant for the said analysis and even the intercept did not find significant. The shoppers stop may use the following equation to estimate RCSAT in terms of RSQS dimensions:

RCSAT $=0.98($ Personal Interaction $)+$ 0.38 (Problem Solving) + 0.24 (Physical Aspect) - 0.42 (Reliability) + error

\section{RSQS dimensions with RCSAT and RCBI}

A multiple regression analysis using step wise method was conducted to predict RCBI in terms of RCSAT \& RSQS dimensions. The analysis showed that the RSQS dimensions, Problem solving and Personal Interaction with RCSAT combined appear to explain RCBI with ' $r$ ' $=0.85$, r-square $=0.72$ and adjusted $r$-square $=0.71$. The regression model fit the data with F-test $=256.5$ significant at $\mathrm{p}<0.001$. The RSQS dimensions like policy, physical aspects and reliability did not appear to contribute in the said analysis. The Shoppers Stop can use the following equation to estimate RCBI:

\section{$\mathrm{RCBI}=0.19+0.56(\mathrm{RCSAT})+0.26$ (Problem Solving) +0.23 (Personal Interaction) + error}

This implies that customer satisfaction in the major determinant to predict customer's future intentions to be with the company or not. The shoppers stop should focus on problem solving and personal interactions factors to make its customers for the repeat purchase. 


\section{Conclusion}

Organized retail is a growing discipline in India and it is expanding its net in all business activities. Shoppers stop is one of the leading high end retail store in multi-brand retail in India, started its business in 1991. The basic purpose of the study was to measure the existing service quality of the said retail stores and trying to find its relations with customer satisfaction and their behavioral intentions. The study revealed that the customer satisfaction is highly correlated with the customer's behavioral intentions (Table 1.1). This means a satisfied customer is likely to purchase again and recommend the services of retail store to its friends and others. This indicates that the Modern retailers like Shoppers Stop should focus on increasing customer satisfaction. Overall customers have good perception of retail service quality provided by Shoppers Stop.
The study also revealed that customer can be made satisfied if the retail service quality is good enough. To make customer satisfied the modern retailers like Shoppers Stop should focus on continuously improving physical infrastructures and facilities. The modern retailers should train their employees in order to customers expecting customer service. The employees should personally interact with employees during the sales process and solve their problems accordingly. The study also supported the existing literature and validated that customer satisfaction is antecedent of customer behavioral intentions. The study also indicated that in order to make customer repeat purchase, modern retailer like Shoppers Stop should focus on personal interaction of employees with its customers and their ability to solve their problems.

\section{References}


[1] Dabholkar, P., Thorpe, D., \& Rentz, J. (1995). A Measure of Service Quality for

Retail Stores: Scale Development and Validation. Journal of The Academy of Marketing Science, 24(1), 3-16. http://dx.doi.org/10.1177/009207039602400 101

[2] Fornell, C. (1992). A National Customer Satisfaction Barometer: The Swedish Experience. Journal Of Marketing, 56(1), 6. http://dx.doi.org/10.2307/1252129

[3] Fornell, C., Johnson, M., Anderson, E., Cha, J., \& Bryant, B. (1996). The American Customer Satisfaction Index: Nature, Purpose, and Findings. Journal of $\begin{array}{lll}\text { Marketing, } & 60(4), & \end{array}$ http://dx.doi.org/10.2307/1251898

[4] Oyeniyi, O., \& Abiodun, A. (2012). Measuring Retail Service Quality in Nigerian Departmental Stores. International Journal Of Economic Behaviour, 2, 37-45.
[5] Rajaram, P., \& Sriram, V. (2014). Measuring Retail Service Quality: A Study on Indian Departmental Stores. International Journal Of Business Management \& Economic Research, 5(1).

[6] Ramayah, T., \& Jasmine, Y. (2003). What drives relationship quality? A study on two retail clothing stores. In Challenges of Globalized Business: The Asian Perspective. Kuantan, Pahang, Malaysia: 5th Asian Academy of Management Conference.

[7] Seth, N., Deshmukh, S., \& Vrat, P. (2005). Service quality models: a review. Int J Qual \& Reliability Mgmt, 22(9), 913-949. http://dx.doi.org/10.1108/026567105106252 11

[8] Sivadas, E., \& Bakera Prewitt, J. (2000). An examination of the relationship between service quality, customer satisfaction, and store loyalty. Intl J Of Retail \& Distrib Mgt, $28(2)$, 73-82. 
http://dx.doi.org/10.1108/095905500103152

23

\section{List of Figures}

Figure 1.1: Customer Age in years

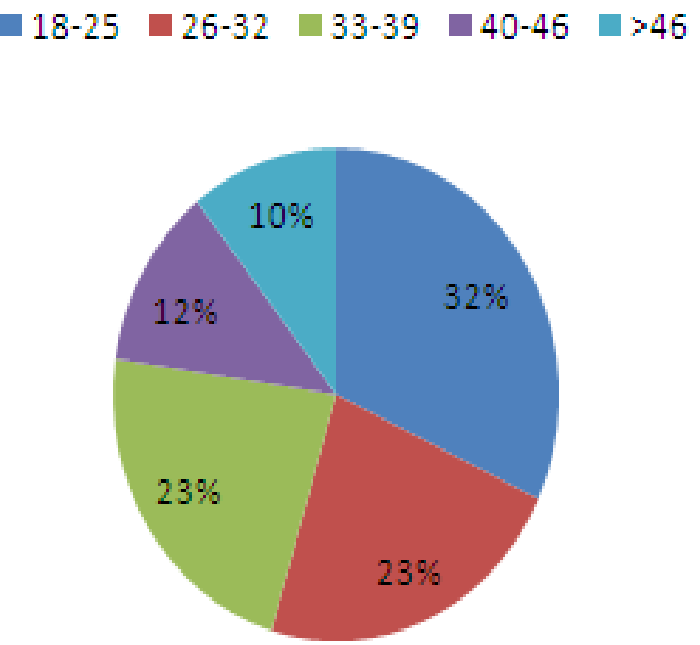

[9] Wikipedia, (2015). Shoppers Stop.

Retrieved 16 December 2015, from

https://en.wikipedia.org/wiki/Shoppers_Stop 
Figure 1.2: Gender

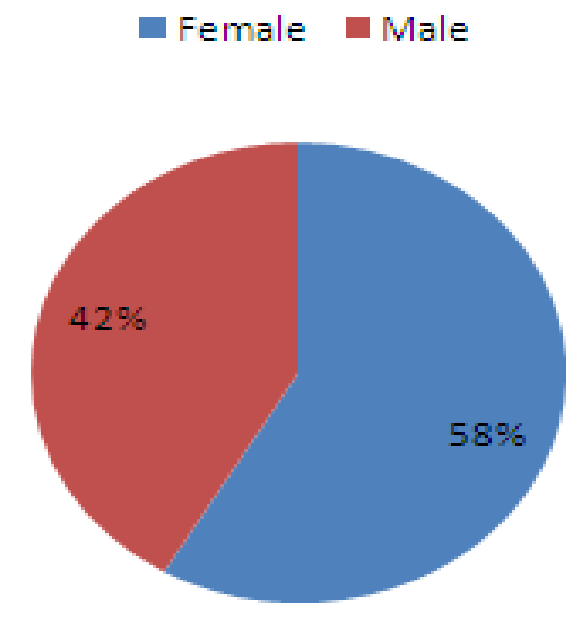

Figure 1.3: Years with Brand Frequency

$\square 0-3 \quad 3-6=6-9 \square>9$

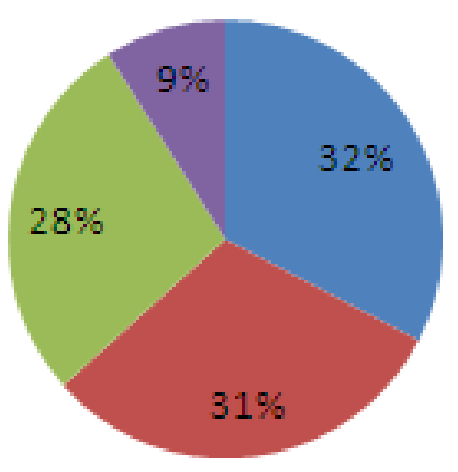


Figure 1.4: Shopping Frequency

$$
1-5 \quad \square-10 \quad \square=10-15 \square>15
$$

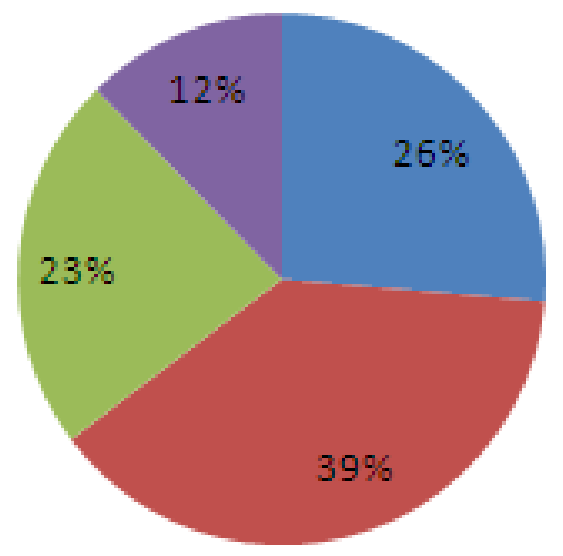

\section{List of Tables}

Table 1.1: Correlations

\begin{tabular}{|c|c|c|c|}
\hline & & RCSAT & RCBI \\
\hline & Pearson Correlation & 1 & $.818^{* *}$ \\
\hline RCSAT & Sig. (2-tailed) & & .000 \\
\hline & $\mathrm{N}$ & 300 & 300 \\
\hline & Pearson Correlation & $818 * *$ & 1 \\
\hline $\mathrm{RCBI}$ & Sig. (2-tailed) & .000 & \\
\hline & $\mathrm{N}$ & 300 & 300 \\
\hline
\end{tabular}

